《研究ノート》

ふ化試験用飼料に対するピリメタミンの添加適量について

$$
\text { 大塚茂・岡基・吉田實 }
$$

農林水産省・家畜衛生試験場, 茨城県筑波郡谷田部町観音台 305

飼料添加物の催奇形性等の遺伝毒性に対しては『 飼料

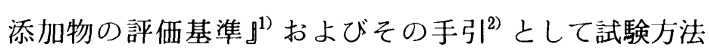
が詳細に示されている。飼料添加物は主として化学物質 であって，その多くは直接細胞内に取り込まれるから， 微生物を用いるインビトロの方法む適用できるし，妊娠 した実験動物の所定の時期に注射するといった方法む適 用できる。しかし, 配合飼料の原料となるべき飼料原料 は，天然の複合物が大部分であって，乙れらは消化され てはじめて細胞内に取り込まれる屯のなので, 注射等の 方法で実験動物に投与することはできないし，微生物に よるインビトロの方法む適用できない。したがって，化 学物質に対して適用できた遺伝毒性の試験方法の大部分 は飼料原料には適用できない。

飼料原料が持っているかもしれない催奇形性を評価す る方法として鶏に給与して種卵をとり, ふ化させて判断 する方法が提案されている。乙の方法は, 奇形学の専門 的知識を必要とせずに誰でむ客観的な評価ができるし， 検体を給与して生産した鵎卵を食用にしてよいかの判断 が同時にでき，操作が簡単で経費む少なくてすむ上に鶏 を犠牲にする必要むないといった多くの特徵をむってい る。正常な飼料を給与した場合の奇形雛の 発生率に関 する基礎データが蓄積されていて, 判断基準 ${ }^{3)}$ が導 かれて扔り，具体的な実施方法についても提案されてい $ろ^{4)}$ 。

提案されている方法) では, 催奇形性物質を含まない 対照区を設定し，検体に上る奇形雔の発生率を，正常な 飼料を給与する場合の奇形雊発生率の $99 \%$ 信頼上限 㑑 ${ }^{3)}$ 之比較して判断する。しかし, 催奇形性の評価の信 頼性を高めるために，催奇形性既知の物質を含む正対照 区を設定して，検体の成績を正負の対照区の成績と比較 して判断するてとが望ましい。

検討の結果, 正対照としてピリメタミンを使用するて とにした。この目的のふ化試験にあたっては, 種䳕が試 験飼料を食べ続けて所定数以上の受精卵を生産するてと が絶対的な必要条件であり,さらに, 正対照にあっては,

1987 年 3 月 3 日受付
受精卵のすべてが発育を中止して奇形雊の発生率が評価 できないようでは目的を達しない。したがって，正対照 物質の給与条件が重要となる。

ピリメタミンはロイコチトゾーン症の䂆方剂として使 用されており, その効果, 使用法, 毒性等については, 秋葉の総説) にまとめられている。それによれば, 飼料 中の添加量が $25 \mathrm{ppm}$ 以上になると貧血等の中毒症状 があらわれ，産卵率む次第に低下する。添加量が 1 2 ppm であれば，受精率やふ化率に対する影響はなかっ た。飼料中のピリメタミンがふ化に影響して催奇形性を 示すためには，ピリメタミンが種卵中に移行し残留する 必要がある。十分な量が種卵中に残留するためには，1000 $\mathrm{ppm}$ 程度の高濃度でなければならないだろうというこ とも予想した。

本研究では, 催奇形性評価試験の正対照としてのピリ メタミンの特性を調べるに先だって, $500 \mathrm{ppm}$ を最高 濃度とする 4 段階の添加量について実験して, 飼料中の ピリメタミンの添加適量を検討した。

\section{実験材料および方法}

約 6 か月齢の白色レグホーン種雌鷄 12 羽を 3 羽を 1 群として, 飼料扔よび飲水を自由に与えて飼育した。ピ リメタミンの投与開始時, 中止時およびその中間に体重 を测定し, 飼料摂取量は試験開始後 8 日目から 18 日間 毎日測定した。

成鵎用試験飼料は, 日本配合飼料 KK 製の飼料添加 剤を含まないものを用いた。ピリメタミンは三共化成工 業 KK 製の純品を用いた。飼料中のピリメタミンの添 加量を， $0,50,100,250$, および, $500 \mathrm{ppm}$ とした。

第 1 群の 3 羽に添加量 $500 \mathrm{ppm}$ の試験飼料を 7 日間 給与した後, ピリメタミン $250 \mathrm{ppm}$ 添加飼料切り替 えて 18 日間飼育した。残りの 3 群には, 無添加飼料を 6 日間与えた後, 添加量 0,50 , および, $100 \mathrm{ppm}$ の試 験飼料を給与して 21 日間飼育した。0 扩よび $50 \mathrm{ppm}$ 添加飼料給与区は, 給与開始後 10 日目に人工授精し, 121 日目から眝卵して，それぞれ 10 個および 13 個を入 卵した。入卵後 5 日目に検卵し, 卵を割って䳕肧の状態 
を観察した。

\section{実験 結 果}

$500 \mathrm{ppm}$ 添加飼料給与区の産卵率の変化を図 1 亿示 した。 1 群 3 羽であるから日による成績の変動が大きい。 理解を助けるために, 第 1 日のみは 1 日の産卵率を示し, その後は 3 日ごとの平均産卵率を図示した。ピリメタミ ンの給与開始後, 産卵率は急速に低下して 7 日目に休産 し，その後はピリメタミン添加量を半減したにもかかわ らず産卵を再開しなかった。ピリメタミン給与開始時の 平均体重は $1.61 \mathrm{~kg}$ であったが，7日目には $1.41 \mathrm{~kg}$ に減少し, その後はピリメタミン添加量を半減したにも かかわらず, 平均体重は $1.32 \sim 1.37 \mathrm{~kg}$ で回復しなか った。 8 日目, すなわち, ピリメタミン添加量半減後 2 日目, から飼料摂取量を測定したが，1日 1 羽あたり 29 〜 $47 \mathrm{~g}$ にすぎず，飼料摂取量も回復しなかった。

0,50 , および, $100 \mathrm{ppm}$ 添加飼料給与区の産卵率と 飼料摂取量の変化を図 2 に示した。いずれも, 3 日間の 平均值を図示している。100 p pm 添加飼料給与区では, 給与開始後産卵率が低下し，14 日目に休産した。飼料 捸取量む対照の $0 \mathrm{ppm}$ 添加飼料給与区に比して，しだ いに減少する傾向であった。 $50 \mathrm{ppm}$ 添加飼料給与区で は, 休産はしなかったが, 産卵率, 飼料摂取量とも減少 する傾向を示した。 3 羽 1 群という小羽数の予備試験な ので, 産卵率の差を統計的に確認することはできないが, 試験終了時の産卵率は, 対照の $0 \mathrm{ppm}$ 添加飼料給与区 と休産した $100 \mathrm{ppm}$ 添加飼料給与区との中間の産卵率 であった。対照の $0 \mathrm{ppm}$ 添加飼料給与区の飼料摂取量 は，1日 1 羽あたり約 $100 \mathrm{~g}$ で少しずつ増加する傾向で あった。てれに対し，50 および $100 \mathrm{ppm}$ 添加飼料給与 区では，しだいに減少する傾向で，試験終了時には，そ れぞれ $79 \mathrm{~g}$ と $89 \mathrm{~g}$ であった。

$0 \mathrm{ppm}$ 添加飼料給与区の試験開始時の平均体重は 1.59 $\mathrm{kg}$ で, 試験終了時には $1.62 \mathrm{~kg}$ となり, わずかながら 増加した。50 ppm 添加飼料給与区では $1.52 \mathrm{~kg}$ から $1.49 \mathrm{~kg}$ に, $100 \mathrm{ppm}$ 添加飼料給与区では $1.66 \mathrm{~kg}$ か ら $1.44 \mathrm{~kg}$ に減少していた。

0 および $50 \mathrm{ppm}$ 添加飼料給与区のふ化試験の結果, $0 \mathrm{ppm}$ 添加飼料給与区では, 入卵数 10 個中無精卵 1 個, 発育中止卵 1 個で, 残り 8 個は発育を続けていた。 50 ppm 添加飼料給与区では, 入卵数 13 個中無精卵 2 個, 発育中止卵 10 個で, 発育を続けていたのは 1 個にすぎ なかった。両区間で, 受精率には差があるとはいえない が, 5 日後の発育中止卵発生率には大差があり, $0 \mathrm{ppm}$ 添加飼料給与区では $11 \%$ \%ちったのに対し, $50 \mathrm{ppm}$ 添加飼料給与区では $91 \%$ で，その差は直接確率計算

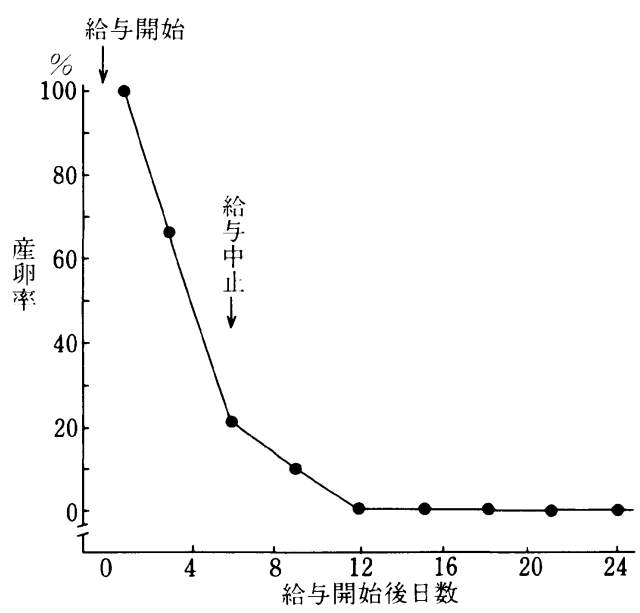

図 1.ピリメタミン $500 \mathrm{ppm}$ 飼料給与区の産卵 率の変化（第 1 日以後は 3 日間の平均値）

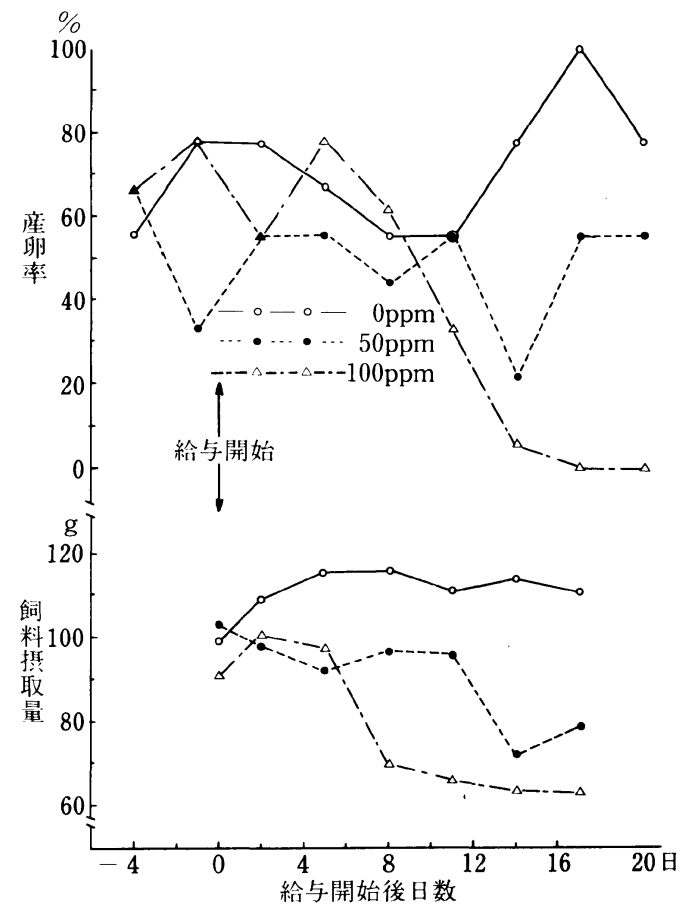

図 2. ピリメタミン給与後の産卵率, 飼料摂取量 の変化 $(3$ 日間の平均を示す)

法 ${ }^{6)}$ で検定して危険率 $0.05 \%$ で有意であった。

5 日目に発育を中止したと判断した $50 \mathrm{ppm}$ 添加飼料 給与区の受精卵のなかには，割卵して検查すると，胚の 発育が著しく遅れているが，な拈生存しているものも認 
められた。

$$
\text { 考察 }
$$

ピリメタミンの毒性は実験開始時に予想したよりはる かに強く, 体重や飼料掑取量の減少, 産卵率の低下がみ られ，やがて休産する。種卵に移行して残留する量も多 いと考えられ，ふ化の初期に既に発育を中止させる。

産卵を継続させるためにはピリメタミンの添加量を 50 ppm 以下にしなければならないという結果であるが, $50 \mathrm{ppm}$ 添加飼料給与区の体重, 飼料摂取量, 産卵率は 給与開始後しだいに減少する傾向であり，試験を 21 日 以上継続するとやがて休産するに至るあのと推定される。 休産しないとしても, ふ化試験に必要な数の種卵を確保 するために多数の雌鶏が必要となるであろう。仮に，十 分な数の種卵がえられたとしても，その $90 \%$ 入卵後 5 日で発育を中止し, 残りの $10 \%$ むその後に発育を中 止するであろうと予想される。発育中止卵発生率は 100 \%となって, 奇形雊の発生率を調べて催奇形性を評価 するてとはできなくなるであろう。

かりに, 発育中止卵発生率が種卵中に残留するピリメ タミン量に比例し, 種卵中の残留量が飼料中のピリメタ ミン添加量に比例するとすれば, 飼料中のピリメタミン 添加量を $20 \mathrm{ppm}$ 程度にすれば, 発育中止卵発生率は 40 \% 程度となり, 奇形雊も発生して, 催奇形性評価にお ける正対照として有効なものになるであろうと推定され る。

この予備実験のデータだけからピリメタミンの添加適 量の上限值を推定することは, 極めて困難であるが, 添 加適量は，おそらく $20 \mathrm{ppm}$ をこえない量であろう。

\section{要約}

飼料原料の催奇形性を評価するふ化試験の正対照飼料 は，種鶏が飼料を食べて受精卵を産み続けるものでなけ ればならず, しかも, ある程度の数の正常な雛と奇形の 雊がかえって, 催奇形性の判断ができることが望ましい。 正対照物質として催奇形性既知のピリメタミンを利用す るととを考えて，その添加適量を検討した。

ピリメタミン $500 \mathrm{ppm}$ 添加飼料を 6 日間給与すると
食欲が減退して休産した。その後はピリメタミン添加量 を半減したにもかかわらず，19 日後でも飼料摂取量も 産卵率も回復しなかった。

ピリメタミン $100 \mathrm{ppm}$ 添加飼料給与区でもしだいに 飼料摂取量が減少し，14 日目に休産した。27 日間の試 験終了時には, 飼料摂取量は $87 \mathrm{~g} /$ 羽/日にすぎなかっ た。なお，そのとき，無添加飼料給与区では，飼料搨取 量は $111 \mathrm{~g} /$ 羽/日であった。

ピリメタミン $50 \mathrm{ppm}$ 添加飼料給与区では産卵を継 続したが，飼料摂取量も産卵率むしだいに減少する傾向 が認められ, 試験終了時には, 飼料摂取量は $79 \mathrm{~g} /$ 羽/ 日，産卵率は $56 \%$ \%なっていた。

$50 \mathrm{ppm}$ 添加飼料給与区の受精卵 11 個中 10 個が入卵 後 5 日目に発育を中止したが, 無添加飼料給与区の受精 卵では 9 個中 1 個が発育を中止しただけであった。

ふ化試験を実施するために必要な数の受精卵を生産し, 催奇形性が判断できるだけの正常な雅と奇形の倠がふ化 するためには, 試験飼料中のピリメタミンの添加量は 20 ppm 以下であろうと推定される。

\section{引用文献}

1）農林水産省畜産局（1977）飼料添加物の評価基準.

2）農林水産省畜産局・水産庁（1980）飼料添加物の 評価基準に基づく試験の手引.

3) Yoshida M., H. Sakai, J. Kitoh, D. Hagano, K. Koba, T. Iwamoto, $M$. Matsushima, H. Bansho, M. InNo, and T. Kato, (1981) Comparison of three feeding experiments with hens to check unknown or unexpected factor in a novel feed ingredient. III. Classification and distribution of deformity of chick embryo in hatchability tests. Japan. Poult. Sci., 18 : $290 \sim 300$.

4）吉田 實（1986）ふ化試験による遺伝毒性の評価 法. 畜産の研究, 40:1047〜1050.

5) AKIBA K. (1970) Leucocytozoonosis of chickens. Nat. Inst. Anim. Hlth. Quart. 10: Suppl.131 147.

6）吉田・實（1983）畜産を中心とする実験計画法. 養賢堂, 東京. 


\title{
Adequate Dietary Level of Pyrimethamine as a Positive Control in a Hatchability Test
}

\author{
Shigeru Ohtsuka, Motoi Oka and Minoru Yoshida \\ National Instutite of Animal Health, Kannon-dai, \\ Yatabe, Ibaraki, 305, Japan
}

A positive control diet in a hatchability test to assess teratogenic effect of a sample should be such that hens take the diet and lay fertile eggs continuously. Furthermore, a certain number of healthy and deformed chicks must be obtained to judge teratogenic effect. Therefore, dietary level of pyrimethamine which is known to be teratogenic and intended to use as a positive control in the hatchability test, should be carefully studied beforehand.

Hens fed a diet containing $500 \mathrm{ppm}$ of pyrimethamine for 6 days lost appetite and stopped laying. Their appetite and egg production did not recover at 19th day after lowering dietary pyrimethamine level to $250 \mathrm{ppm}$.

Hens fed a diet containing $100 \mathrm{ppm}$ of pyrimethamine lost appetite gradually and stopped laying at 14 days after feeding the diet. Their feed intake at the end of the 27-day experimental period was $87 \mathrm{~g} /$ head/day, comparing with $111 \mathrm{~g}$ of hens fed a control diet.

Hens fed a diet containing $50 \mathrm{ppm}$ of pyrimethamine laid continuously, but a trend of gradual decreae of feed intake and egg production was observed. At the end of the experimental period, their feed intake and egg production were $79 \mathrm{~g} / \mathrm{head} /$ day and $56 \%$, respectively.

Ten fertile egg out of 11 laid by the hens fed the diet containing $50 \mathrm{ppm}$ of pyrimethamine stopped growing after 5 days in an incubator, while only one fertile egg out of 9 laid by the control hens stopped growing.

Adequate dietary level of pyrimethamine to get enough fertile eggs for a hatchability test in which a certain number of normal and deformed chicks could be obtained was suspected to be less then $20 \mathrm{ppm}$.

(Japan. Poult. Sci., 24, 259 262, 1987) 